\title{
Monitoring and Evaluation of PV Pumping System Performance Installed in The Algeria's Sahara City of Adrar
}

\author{
Mohammed Yaichi ${ }^{1}$, Abdelkrim Mammeri ${ }^{1}$, and Mohammed-Karim Fellah ${ }^{2}$ \\ ${ }^{1}$ Unité de Recherche en Energies Renouvelables en Milieu Saharien, URERMS, Centre de \\ Développement des Energies Renouvelables, CDER, 01000, Adrar, Algeria \\ ${ }^{2}$ Intelligent Control and Electrical Power Systems Laboratory, Djillali Liabes University of \\ Sidi-Bel-Abbes, Algeria
}

\begin{abstract}
The Sunbelt area like Algeria, specially the Saharan medium by its arid nature and the availability of huge solar irradiance can be a good choice of the application of the photovoltaic (PV) system. Water pumping by PV system for irrigation purposes can be considered as one of the basic needs in the rural areas of Algeria. PV modules are given a power rating at standard test conditions (STC) of $1000 \mathrm{~W} / \mathrm{m}^{2}$, AM1.5 and a module temperature $25^{\circ} \mathrm{C}$, but these conditions do not represent what is typically experienced under outdoor operation. To improve the performances of such type of systems, a study based on outdoor experimental tests is necessary, to establish how much energy is produced and the major parameters that most influence on their quality. The main objective of this paper is to review the state of the art of PV systems in the Adrar Desert of Algeria by the analysis of the operational data of the PV installation. Sophisticated Verification method so called SV method has been used to evaluate a PV pumping system performance during seven months. Differences between real and installed energy of up to $18 \%$ have been detected. It has been observed that the high output gain due to the operating condition in an extreme low module temperature. On the basis of these monitoring results, the performance of PV systems is compared to the measured performance of residential PV systems installed in other countries. The results indicated that the motor-pump efficiency changed by the pumping head.
\end{abstract}

Keywords: PV pumping system, Desert of Algeria, Monitoring data, Performance ratio, Losses, Evaluation.

\section{Introduction}

The evaluation of the photovoltaic (PV) systems seems to be very important in order to acquire the deployment of more reliable PV technologies for the future. The energy production of a photovoltaic system primarily depends on the weather conditions of the geographical location where the system is installed and on a number of other factors such as the orientation profile, shading, temperature effect and the power loss in wiring and inverters. The possible PV potential, which is going to widely assist the use of this technology, especially for countries with high solar irradiation can only be provided through the evaluation and detailed outdoor field analysis of the performance of different installed PV systems. Parameters such as the energy yield, performance ratio and system efficiency have been used in order to make a comparison between various kinds of installed PV system technology [1, 2, 3].

Monitoring data provides certainty about electricity yields, available irradiation, and module temperatures. However, not all loss mechanisms can be monitored, at least not with reasonable effort. Several publications report evaluation of PV systems [2, 3] but do not estimate the parameters that affect and individually on energy production. Other reports [5] propose a method for estimating the irradiance on partially shaded system. In this method, a survey of the surroundings based on teodolite reading (topographic coordinates) of only relevant points of the shading objects were done, this is done by carrying out a photographic sweep from East to West using a camera, in order to record a sequence of photographs for the PV generator surroundings. Other works [4] use the PV system simulation software "Zenit" developed at Fraunhofer ISE, for the modeling.

Received: December $29^{\text {th }}, 2014$. Accepted: May $2^{\text {nd }}, 2016$

DOI: 10.15676/ijeei.2016.8.2.2 
The evaluation method OV (Ordinary Verification) was developed largely by K. Kurokawa [6] and was detailed by T. Oozeki and al [7], or a PV system is monitored by a simple data acquisition system when necessary (hourly in-plane irradiation, PV array temperature, array output power, hydraulic power output (power from utility). The method based of other detailed parameters has become possible by SV (Sophisticated Verification) procedure. In contrast with ordinary procedure, according to $\mathrm{SV}$ method, shading factor $\mathrm{K}_{\mathrm{HS}}$, load matching factor $\mathrm{K}_{\mathrm{PM}}$, other array factor $\mathrm{K}_{\mathrm{PO}}$ can be estimated additionally. This method, consider that of the clearsky power pattern consists only of partial shading and full shading because the mismatch hardly occurs in a clear day, it is naturally omitted by the extraction of hourly maximum values $[7,11]$.

The results presented in this paper allow extracting conclusions about the expected energy production of PV systems at the test site in the Adrar Desert of Algeria and about the energy production losses due their climate nature. Sophisticated Verification method so called SV method has been used to evaluate a PV pumping system performance during seven months, which provides useful information about the seasonal behavior of the system. The results are compared with previous analysis of the operational performance of residential PV systems installed in Japan, Belgium, Korea and Germany.

\section{System Configuration}

Monitoring data are including a PV pumping system data which is composed of $2 \mathrm{mc}-\mathrm{Si}$ Solar ET-M536-75W modules technology. The orientation is full south and the tilt angle is 29 degrees. Figure 1 shows the photo of the system to be evaluated and Table 1 and 2 summarizes the types and manufacturers of the installed PV modules and the measuring devices used. The data acquisition system automatically will be switched on at every one minute. PV system performance data are normally taken by data acquisition system for the evaluation of long-term energy performance; all data were processed on hourly basis for seven months measuring period.

The outputs current and voltage are measured; meteorological data such as irradiance and the module temperature are also measured. They are interfaced to a PC based data logging device Hydra, FLUKE type. The daily pumped water quantity was measured by counter for a day. In this field test pumping, the data is monitored for three different pumping heads $(1.6 \mathrm{~m}$, $1.185 \mathrm{~m}$ and $3.95 \mathrm{~m})$.

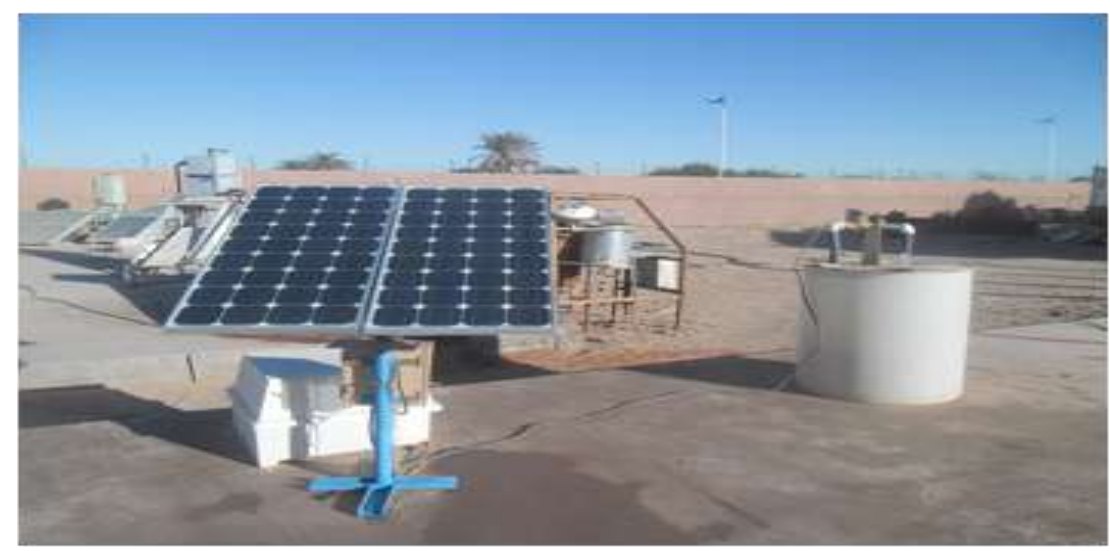

Figure 1. Photos of the system to study 
Table 1. PV Motor-pump specifications

\begin{tabular}{|c|c|c|c|c|}
\hline & & Module Type & $\begin{array}{l}\text { mc-Si Solar } \\
\text { ET-M53675 }\end{array}$ & \\
\hline & & $\mathrm{P}_{\max }$ & 75 & $\mathrm{~W}$ \\
\hline & & $\mathrm{I}_{\mathrm{pm}}$ & 4.31 & $\mathrm{~A}$ \\
\hline PV Module & & $\mathrm{V}_{\mathrm{pm}}$ & 17.4 & $\mathrm{~V}$ \\
\hline & & $\mathrm{I}_{\mathrm{sc}}$ & 4.72 & A \\
\hline & & $\mathrm{V}_{\mathrm{oc}}$ & 21.73 & $\mathrm{~V}$ \\
\hline & & $\alpha_{\text {pmax }}$ & -0.004 & $\mathrm{~W} /{ }^{\circ} \mathrm{C}$ \\
\hline & & Area A & $119 \times 52.52$ & $\mathrm{Cm}^{2}$ \\
\hline & & Series & 2 & \\
\hline & & Parallel & 1 & \\
\hline Subsystem & Inverter & Type & $\begin{array}{c}\text { LORENTZ } \\
\text { EC-PWM } \\
\text { 3phase }\end{array}$ & \\
\hline brushless & & Capacity & 150 & $\mathrm{~W}$ \\
\hline DC motor & & Input voltage & $12-24 \mathrm{DC}$ & $\mathrm{V}$ \\
\hline & & Output voltage & 4-18 AC & $\mathrm{V}$ \\
\hline & $\begin{array}{l}\text { Sub- } \\
\text { System }\end{array}$ & $\begin{array}{l}\text { Motor-pump } \\
\text { type }\end{array}$ & $\begin{array}{c}\text { PS150 C-SJ5- } \\
8\end{array}$ & \\
\hline
\end{tabular}

Table 2. Measuring devices

\begin{tabular}{|l|c|}
\hline Parameter & Device \\
\hline Irradiance & kipp zonen CM11 Pyranometer \\
\hline PV voltage & LV 25-P Hall effect \\
\hline PV current & LF 306-S/SP10 LEM Hall effect \\
\hline PV cell temperature & Thermo resistance K \\
\hline $\begin{array}{l}\text { Daily pumped water } \\
\text { quantity }\end{array}$ & Counter \\
\hline
\end{tabular}

\section{Performance analysis methodology $[8,9]$}

The final PV system yield $Y_{f}$ is the net energy output $E_{P}$ divided by the nameplate DC power $\mathrm{P}_{\mathrm{AS}}$ of the installed PV array. It represents the number of hours that the PV array would need to operate at its rated output power to provide the same energy. The units are hours or $\mathrm{kWh} / \mathrm{kW}$, with the latter preferred by the authors because it describes the quantities used to derive the parameter. The $\mathrm{Y}_{\mathrm{f}}$ normalizes the energy produced with respect to the system size; consequently, it is a convenient way to compare the energy produced by PV systems of different size:

$$
\mathrm{Y}_{\mathrm{f}}=\frac{\mathrm{E}_{\mathrm{P}}}{\mathrm{P}_{\mathrm{AS}}}=\frac{\sum \mathrm{P}_{\mathrm{PV}}}{\mathrm{P}_{\mathrm{AS}}} \text { (hours or } \mathrm{kWh} / \mathrm{kW} \text { ) }
$$

Where: $\mathrm{P}_{\mathrm{PV}}$ is the output system power during one hour. It is depends closely on the climatic conditions (solar irradiance $\mathrm{G}$ and temperature $\mathrm{T}_{\mathrm{c}}$ ), $\mathrm{P}_{\mathrm{AS}}[\mathrm{kW}]$ the array capacity under STC.

$$
\mathrm{P}_{\mathrm{PV}}=\sum_{\min =1}^{\min =60} \mathrm{P}_{\mathrm{P}}=\sum_{\min =1}^{\min =60}\left(\mathrm{~V}_{\mathrm{PV}}\left(\mathrm{G}, \mathrm{T}_{\mathrm{c}}\right) \cdot \mathrm{I}_{\mathrm{PV}}\left(\mathrm{G}, \mathrm{T}_{\mathrm{c}}\right)\right)
$$

Where: $\mathrm{P}_{\mathrm{p}}$ is the DC output power from the PV array, $\mathrm{V}_{\mathrm{PV}}=\mathrm{DC}$ operating voltage $[\mathrm{V}] ; \mathrm{I}_{\mathrm{PV}}=\mathrm{DC}$ operating current $[\mathrm{A}]$. 
The reference yield $Y_{r}$ is the total in-plane irradiance $H_{P}$ divided by the PV reference irradiance $G_{S}$. It represents an equivalent number of hours at the reference irradiance. $G_{S}$ equals $1 \mathrm{~kW} / \mathrm{m}^{2}$, then $Y_{\mathrm{r}}$ is the number of peak sun-hours or the solar radiation in units of $1 \mathrm{~kW} / \mathrm{m}^{2}$. The $Y_{r}$ defines the solar radiation resource for the PV system. It is a function of the location, orientation of the PV array, and month-to-month and year-to-year weather variability:

$$
\mathrm{Y}_{\mathrm{r}}=\frac{\mathrm{H}_{\mathrm{P}}}{\mathrm{G}_{\mathrm{S}}}=\frac{\sum \mathrm{G}_{\mathrm{mes}}}{\mathrm{G}_{\mathrm{S}}} \text { (hours) }
$$

Where: $G_{m e s}$ is in-plan irradiance during one hour, $H_{P}$ the total irradiation in the given time period $\left[\mathrm{kWh} / \mathrm{m}^{2}\right], \mathrm{G}_{\mathrm{S}}$ the irradiance under STC.

In addition to the energy production by a PV system the performance is further characterized by the performance ratio PR which is defined as the ratio of the measured system efficiency and the nominal efficiency of the PV modules (i.e. specifically, the performance ratio is the ratio of the actual and theoretically possible energy outputs). It is largely independent of the orientation of a PV system, the incident solar irradiation and system size. For this reason, the performance ratio can be used to compare PV plants supplying the grid at different locations all over the world. The performance ratio is one of the most important variables for evaluating the efficiency of a PV system. The performance ratio PR of a PV system is the value provided by dividing $Y_{\mathrm{f}}$ by the $\mathrm{Y}_{\mathrm{r}}$. It is a useful way of quantifying the overall effect of losses due to the inverter, wiring, power mismatch and other losses such as PV module temperature, optical reflection, soiling and downtime failures.

$$
\mathrm{PR}=\frac{\mathrm{Y}_{\mathrm{f}}}{\mathrm{Y}_{\mathrm{r}}}=\frac{\mathrm{E}_{\mathrm{P}}}{\mathrm{H}_{\mathrm{P}} \times \mathrm{P}_{\mathrm{AS}}} \text { (dimensionless) }
$$

Although the performance ratio gives a global idea of the system behavior, it is very difficult to use it as a tool to identify components that are not working properly and is thus provided on an annual basis. Large decreases in PR indicate events that significantly impact performance such as inverters not operating. Small decreases in PR indicate that a less severe problem exists [9].

Generating power $\left(\mathrm{E}_{\mathrm{p}}\right)$ of $\mathrm{PV}$ system for a period is calculated by the following equation [10]:

$$
\mathrm{E}_{\mathrm{p}}=\frac{\mathrm{P}_{\mathrm{AS}} \mathrm{H}_{\mathrm{P}}}{\mathrm{G}_{\mathrm{S}}} \mathrm{PR}(\mathrm{kWh})
$$

\section{Photovoltaic energy conversion loss model of PV systems (Sophisticated Verification method)}

A. Introduction

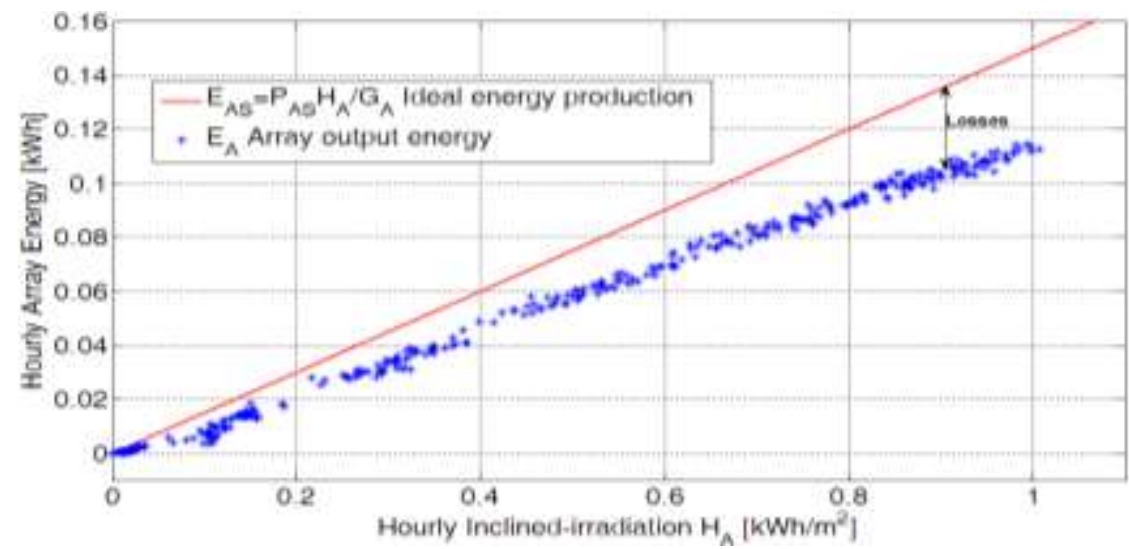

Figure 2. Identification of the ideal energy production and losses 
A scattered graph as shown in Figure 2 gives very important information. Horizontal axis shows all the data in-plane irradiation at each hour during the same month. Vertical axis corresponds to hourly system output energy. An upper straight line corresponds to ideal energy production by array with its capacity $\mathrm{P}_{\mathrm{AS}}$ under irradiation $\mathrm{H}_{\mathrm{A}}$.

If the input and output energies of a given component $\mathrm{x}$ are denoted $\mathrm{E}_{\mathrm{xi}}$ and $\mathrm{E}_{\mathrm{xo}}$, parameter $\mathrm{K}_{\mathrm{x}}$ is defined by the ratio of two energies as indicated in Figure 3 [6].

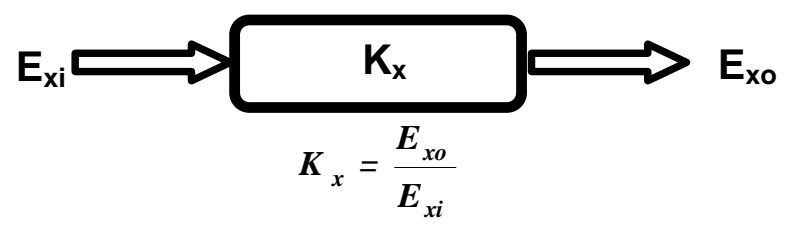

Figure 3. General definition of system parameters

Therefore, the loss is expressed by:

$$
1_{\mathrm{x}}=\mathrm{E}_{\mathrm{xi}}-\mathrm{E}_{\mathrm{xo}}=\mathrm{E}_{\mathrm{xi}}\left(1-\mathrm{K}_{\mathrm{x}}\right)(\mathrm{kWh})
$$

For example, if output energy of the modules $\mathrm{E}_{\mathrm{A}}=\mathrm{V}_{\mathrm{PV}} \cdot \mathrm{I}_{\mathrm{PV}}$, the cell temperature factor $\mathrm{K}_{\mathrm{PT}}$ is calculated from the following equation (7) using temperature coefficient: $\alpha_{\mathrm{pmax}}\left[\mathrm{W} /{ }^{\circ} \mathrm{C}\right]$ specific to a module [7].

$$
\mathrm{K}_{\mathrm{PT}}=1+\alpha_{\mathrm{pmax}}\left(\mathrm{T}_{\mathrm{c}}-25\right)(\mathrm{kWh})
$$

With: $\mathrm{T}_{\mathrm{c}}$ is module temperature.

If $\mathrm{T}_{\mathrm{c}}>25^{\circ} \mathrm{C}$, the $\mathrm{K}_{\mathrm{PT}}<1\left(\mathrm{l}_{\mathrm{x}}>0\right)$. On the opposite, the $\mathrm{K}_{\mathrm{PT}}>1\left(\mathrm{l}_{\mathrm{x}}<0\right)$. The positive value of $1_{\mathrm{x}}$ means the loss and negative value means the gain in the loss analysis, $\left(l_{x}=0\right)$ no losses.

The loss due to the temperature dependence will be calculated by:

$$
1_{\mathrm{PT}}=\mathrm{E}_{\mathrm{AT}}-\mathrm{E}_{\mathrm{A}}=\frac{\alpha_{\mathrm{p} \max }\left(25-\mathrm{T}_{\mathrm{c}}\right)}{1+\alpha_{\text {pmax }}\left(\mathrm{T}_{\mathrm{c}}-25\right)} \mathrm{E}_{\mathrm{A}}(\mathrm{kWh})
$$

$\mathrm{E}_{\mathrm{AT}}$ is array output energy converts into cell temperature on STC.

Complicated and non-linear operations of PV system are assumed to be simple and linear factors and generating power are easily calculated by those factors. The relationship of main design parameters is expressed in Figure 4.

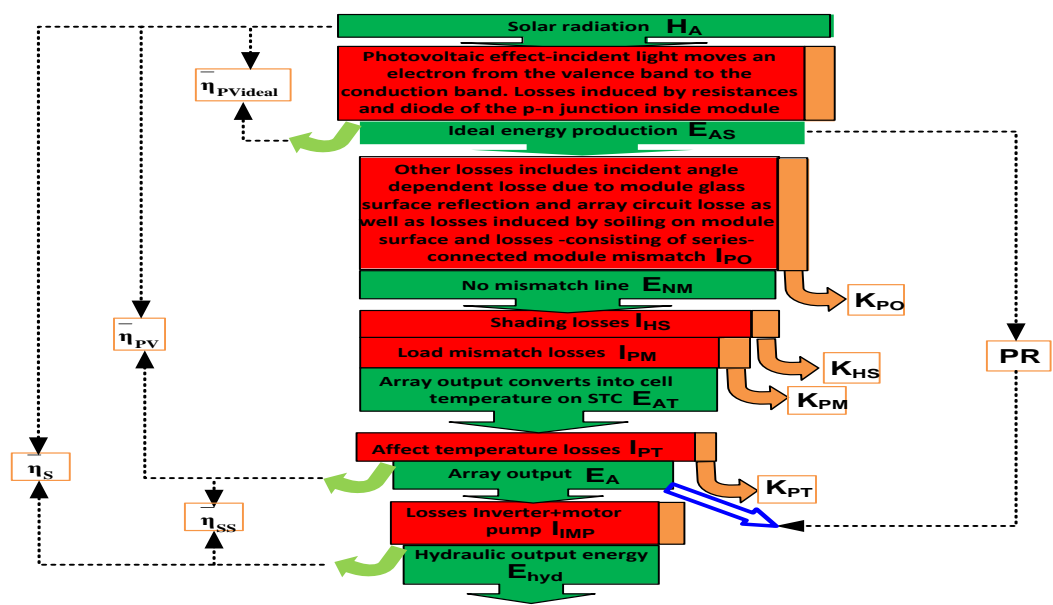

Figure 4. Photovoltaic energy conversion and loss model of PV pumping system 
By using data acquisition system, several energy values are calculated on daily basis, monthly basis or annual basis. These energy data can be utilized to obtain system parameters such as system performance ratio $\mathrm{PR}$, cell temperature factor $\mathrm{K}_{\mathrm{PT}}$, power conditioner circuit and motor-pump factor $\mathrm{K}_{\mathrm{IMP}}$ by a simple calculation.

Losses by inverter and motor-pump are calculated from the following equation according to the difference of $\mathrm{E}_{\mathrm{A}}$ and $\mathrm{E}_{\mathrm{hyd}}$ :

$$
1_{\text {IMP }}=\mathrm{E}_{\mathrm{A}}-\mathrm{E}_{\text {hyd }}
$$

$\mathrm{E}_{\text {hyd }}$ is hydraulic output energy.

Normally other useful parameters can be identified in addition, i.e., shading factor $\mathrm{K}_{\mathrm{HS}}$, load mismatching factor $\mathrm{K}_{\mathrm{PM}}$ and other array factor $\mathrm{K}_{\mathrm{PO}}$. The identification of these additional parameters has been quite difficult so far. So it is even by a specially planned monitoring method. In this paper, a novel method developed by researchers Japanese called SV (Sophisticated Verification) method has been used to obtain performance accurate from a PV system representing different PV modules technologies.

B. Making no mismatch line $[6,7,11]$
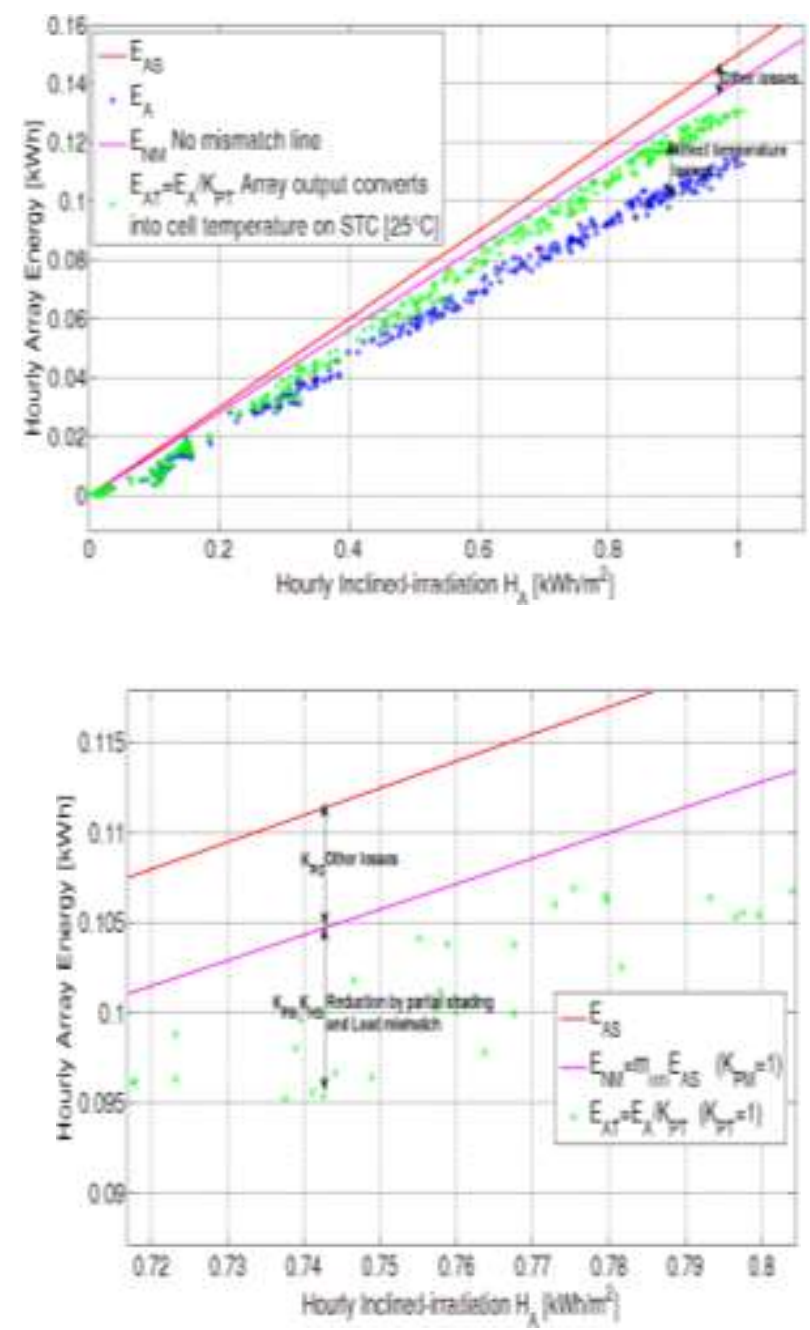

Figure 5. No mismatch line and other array factor 
A scattered graph as shown in Figure 5 also gives very important information. An upper straight line corresponds to ideal energy production: $\mathrm{E}_{\mathrm{AS}}$. Scattered dots are all the hourly data $\mathrm{E}_{\mathrm{AT}}$ [it converts into cell temperature: $25^{\circ} \mathrm{C}$ of standard test condition]. A lower straight line is drawn as the upper envelope of scattered points by changing $\mathrm{m}_{\mathrm{nm}}$ in Eq. (10). The line is called "no mismatch line"': $\mathrm{E}_{\mathrm{NM}}$ means the most efficient performance and no shading, no mismatch and not due to temperature dependence. When data are located below this line, it means partial shading (which means that shadow exists on a part of PV array surface) and/or $K_{P M} \neq 1$ (it is considered that MPPT does not work well). Then, the remaining part of $\mathrm{E}_{\mathrm{NM}}-\mathrm{E}_{\mathrm{AT}}$ is considered to be $\mathrm{P}_{\max }$ mismatch component.

$$
\mathrm{E}_{\mathrm{NM}}=\mathrm{m}_{\mathrm{nm}} \mathrm{P}_{\mathrm{AS}} \frac{\mathrm{H}_{\mathrm{A}}}{\mathrm{G}_{\mathrm{S}}}
$$

\section{Principle of shading rate definition for a month}

$$
\mathrm{K}_{\mathrm{HS}}= \begin{cases}\frac{\mathrm{E}_{\mathrm{AM}}-0.2 \mathrm{E}_{\mathrm{Ath}}}{0.8 \mathrm{E}_{\mathrm{Ath}}} & \text { if } \mathrm{E}_{\mathrm{AM}}>0.2 \mathrm{E}_{\mathrm{Ath}} \\ 1 & \text { if } \mathrm{E}_{\mathrm{AM}}<0.2 \mathrm{E}_{\mathrm{Ath}}\end{cases}
$$
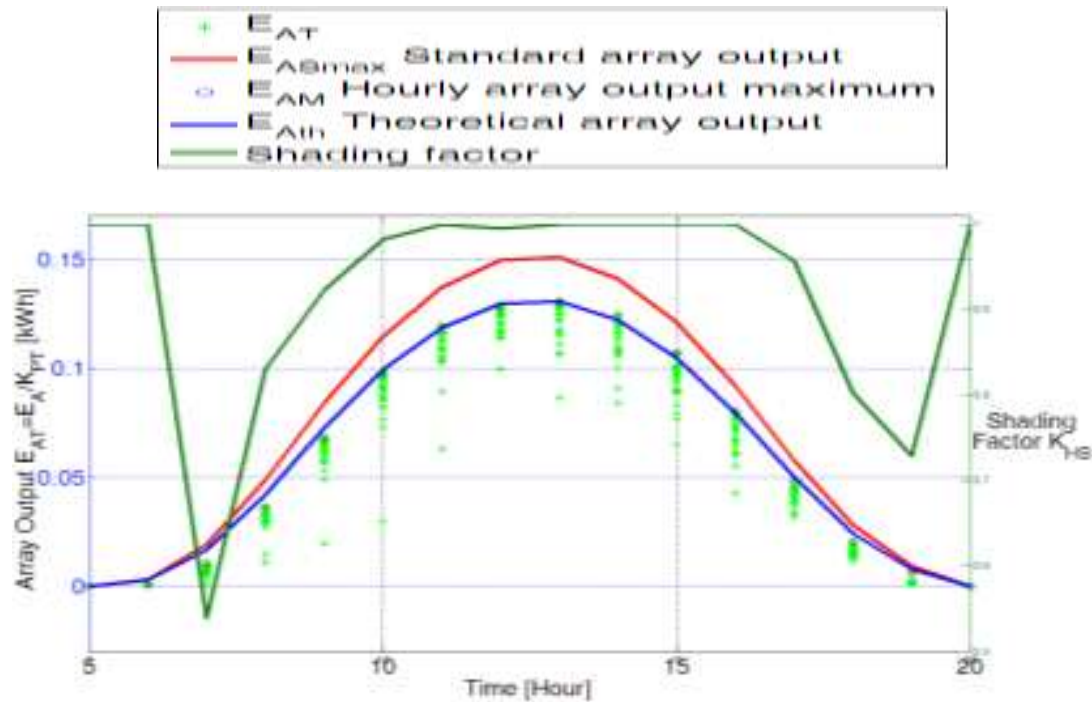

(a)

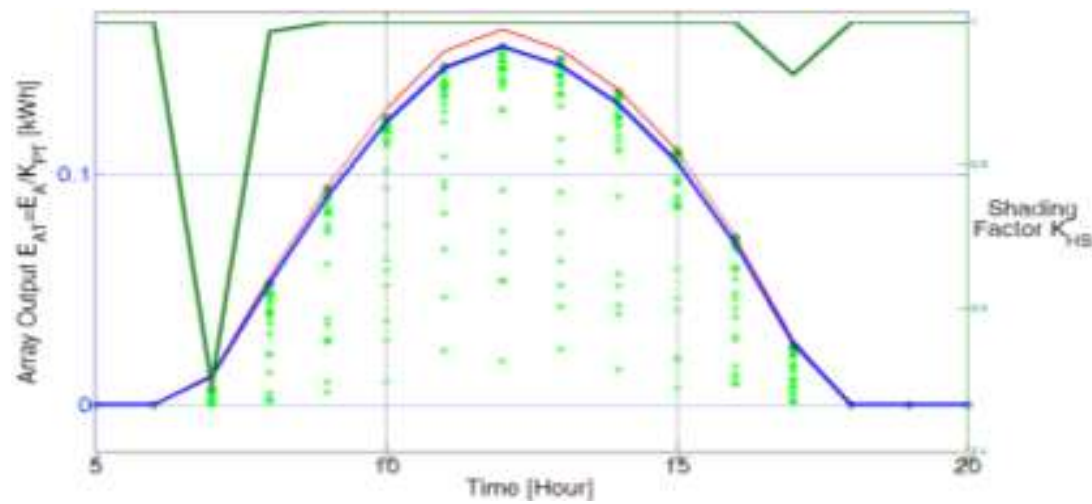

(b)

Figure 6. A typical example of identification of shading effect (a) July, (b) November 
The principle of shading rate definition for a month has the following assumption. The shading should be the shadow from obstacles such as building, tree, etc. There needs to be a day with fine weather in a month one day at least. There is at least one datum that has no losses of the shading among the data for a month, i.e. if shading is assumed to exist every day almost in the same way during the same month, maximum values for a specific hour cannot exceed a shaded level of a clear day. In order to apply for the principle of shading rate, maximum array output curve: $\mathrm{E}_{\mathrm{AM}}$ is made, it has only extracted $\mathrm{E}_{\mathrm{AT}}$ of the maximum data for every hour, which contain shading effects $[6,7]$.

Figure 6 gives a typical example of the shading effect that was observed in July and November 2014 by system mentioned above. The vertical axis of Figure 6 corresponds to hourly array output energy at standard cell temperature $25^{\circ} \mathrm{C}$. As a preparation, a top curve $\mathrm{E}_{\mathrm{ASmax}}$ is calculated by using a clear-day pattern irradiance and array rated output $\mathrm{P}_{\mathrm{AS}}$, is adjusted to fit the array output maximum values for each hourly period. When shading effects are identified, the $\mathrm{E}_{\mathrm{AM}}$ is compared to the theoretical curve $\mathrm{E}_{\mathrm{Ath}}$ that has no effect on shading. $E_{A t h}$ is obtained to fit as an envelope, this fitting is shown as $m \cdot E_{A S m a x}[7,11,12]$. Estimation of value $\mathrm{m}$ is explained to find a maximum value of $\mathrm{m}$ by an iterative algorithm so that any extracted maximum values, $\mathrm{E}_{\mathrm{Am}}$ do not exceed an estimated curve at any points. A shading factor $\left(\mathrm{K}_{\mathrm{HS}}\right)$ detected in array output maximum values $\mathrm{E}_{\mathrm{AM}}$ for each hourly period. Apparently, the effect of shading can be recognized from $7^{\mathrm{H}}: 00$ to $10^{\mathrm{H}}: 00$ and $16^{\mathrm{H}}: 00$ to $19^{\mathrm{H}}: 00$ as shown in July (graph (a)) and at $7^{\mathrm{H}}$ and at $17^{\mathrm{H}}$ as shown in November (graph (b)). In this case, the difference in the point $\mathrm{E}_{\mathrm{AM}}$ and the point $\mathrm{E}_{\mathrm{Ath}}$ above the curve $\mathrm{E}_{\mathrm{ASmax}}$ is caused by the influence of shading. If a diffused component of clear-day irradiance is assumed $20 \%$ that is on a standard fine day because $\mathrm{E}_{\mathrm{AM}}$ is close to a fine weather day, a shading factor can be calculated by equation (11). It is considered that no shading takes place for the diffused component.

\section{Hourly shading losses identification}

Losses by shading are identified from the following, using the fact that $\mathrm{K}_{\mathrm{HS}}$ for each hour is only a part of direct irradiation:

$1_{\mathrm{HS}}=\mathrm{P}_{\mathrm{AS}}\left(1-\mathrm{K}_{\mathrm{d}}\right) \mathrm{H}_{\mathrm{A}}\left(1-\mathrm{K}_{\mathrm{HS}}\right)$

$\mathrm{K}_{\mathrm{d}}$ diffused coefficient (dimensionless number).

Overall results for the SV method include the aforementioned shading losses and energy no mismatch. As the calculation of these two parameters was making, the calculation of other parameters were very easy.

\section{E. Hourly load mismatch losses identification}

It is assumed that the difference between $\mathrm{E}_{\mathrm{NM}}$ and $\mathrm{E}_{\mathrm{AT}}$ corresponding to $\mathrm{H}_{\mathrm{A}}$ contain $\mathrm{l}_{\mathrm{HS}}$ and load mismatch losses: $1_{\mathrm{PM}}$. Losses by load mismatch are identified from the following Eq. (13) using each loss:

$$
1_{\mathrm{PM}}=\left(\mathrm{E}_{\mathrm{NM}}-1_{\mathrm{HS}}\right)-\mathrm{E}_{\mathrm{AT}}
$$

\section{F. Other losses identification}

Other losses are the undissociating factors that may consist of array circuit losses, soiling on module surface, the incident-angle-dependent reflection losses, etc. These are the differences between $\mathrm{E}_{\mathrm{AS}}$ and $\mathrm{E}_{\mathrm{NM}}$ corresponding to $\mathrm{H}_{\mathrm{A}}$ : It can be identified from the following equation:

$$
1_{\mathrm{PO}}=\mathrm{E}_{\mathrm{AS}}-\mathrm{E}_{\mathrm{NM}}
$$

\section{G. Motor-pump efficiency}

The daily pumped water quantity $\mathrm{Q}_{\mathrm{d}}\left[\mathrm{m}^{3} /\right.$ day] was measured by counter for a day. After performing the calculation process, the monthly pumped water quantity is defined as: 


$$
\mathrm{Q}_{\mathrm{m}}=\sum_{\mathrm{n}=1}^{\mathrm{N}} \mathrm{Q}_{\mathrm{dn}}
$$

Where: $\mathrm{N}$ indicate the number of day per month.

For a month, $\mathrm{Q}_{\mathrm{m}}\left[\mathrm{m}^{3} / \mathrm{month}\right]$ and head $\mathrm{H}[\mathrm{m}]$ are defined; it is easy to calculate the pump energy output [kWh] (i.e. hydraulic energy output) as shown in equation $(16)[13,14]$.

$\mathrm{E}_{\mathrm{hyd}}=\mathrm{CH} \cdot \mathrm{Q}_{\mathrm{m}} \cdot \mathrm{H}$

$\mathrm{CH}=\frac{\rho \cdot \mathrm{g}}{3600}=2.725: \rho=10^{3} \mathrm{~kg} \cdot \mathrm{m}^{-3}$ water volumic mass the constant, $\mathrm{g}=9.81 \mathrm{~m} \cdot \mathrm{s}^{-2}$ the constant of gravity.

Monthly average motor-pump efficiency can quite simply be calculated from:

$$
\bar{\eta}_{\text {IMP }}=\bar{\eta}_{\mathrm{SS}}=\frac{\mathrm{E}_{\mathrm{hyd}}}{\mathrm{E}_{\mathrm{P}}} \times 100 \%=\frac{\mathrm{E}_{\mathrm{hyd}}}{\sum_{\text {month }} \mathrm{E}_{\mathrm{A}}} \times 100 \%
$$

\section{H. System and array efficiencies}

The system efficiency and array efficiency may be calculated as follows:

$$
\begin{aligned}
& \bar{\eta}_{\mathrm{S}}=\frac{\mathrm{E}_{\mathrm{hyd}}}{\mathrm{H}_{\mathrm{P}} \cdot \mathrm{A}} \times 100 \%=\frac{\mathrm{E}_{\mathrm{hyd}}}{\sum_{\text {month }} \mathrm{H}_{\mathrm{A}} \cdot \mathrm{A}} \times 100 \% \\
& \bar{\eta}_{\mathrm{PV}}=\frac{\mathrm{E}_{\mathrm{A}}}{\mathrm{H}_{\mathrm{P}} \cdot \mathrm{A}} \times 100 \%=\frac{\mathrm{E}_{\mathrm{A}}}{\sum_{\text {month }} \mathrm{H}_{\mathrm{A}} \cdot \mathrm{A}} \times 100 \%
\end{aligned}
$$

Where: Array area $\left[\mathrm{m}^{2}\right]$.

While the array ideal efficiency (PV modules efficiency at STC) may be calculated as follows:

$$
\bar{\eta}_{\text {PVideal }}=\frac{\sum_{\text {month }} \mathrm{E}_{\mathrm{AS}}}{\mathrm{H}_{\mathrm{P}} \cdot \mathrm{A}} \times 100 \%=\frac{\mathrm{P}_{\mathrm{AS}} \cdot \mathrm{H}_{\mathrm{P}}^{\mathrm{H}} / G_{S}}{\mathrm{H}_{\mathrm{P}} \cdot \mathrm{A}} \times 100 \%=\frac{\mathrm{P}_{\mathrm{AS}}}{\mathrm{G}_{\mathrm{S}} \cdot \mathrm{A}} \times 100 \%=\eta_{\text {PVideal }}=12 \%
$$

\section{Analysis results}

A. Compensation factor and the loss rate

The SV method was evaluated by losses: $1_{x}$; compensation factors: $K_{x}$; and loss ratios: $\lambda_{x}$. Compensation factors are coefficient based on the parameter analyzing method [7], and an output ratio to the input in each loss process. Loss ratios are defined as the ratio of the rate for which each loss occurs to the system input. The relation between $l_{x}$ and $\lambda_{x}$ is shown below:

$$
\lambda_{\mathrm{x}}=\frac{1_{\mathrm{x}}}{\left(\mathrm{P}_{\mathrm{AS}} \mathrm{H}_{\mathrm{P}} / \mathrm{G}_{\mathrm{s}}\right)}
$$

\section{B. Results and discussions}

During the test period of PV pumping system (May-November 2014), solar radiation per day in each month range from 2.32 and $7.58 \mathrm{kWh} / \mathrm{m}^{2} /$ day in the plane of the PV modules, while array energy output ranged between 0.28 and $1.01 \mathrm{kWh} /$ day. Long-term test results indicate the relation of daily water discharge $\left(\mathrm{m}^{3} /\right.$ day) to the total daily array energy output $(\mathrm{kWh} /$ day). For the three pumping head profiles, the results showed that water delivery by the pump ranged from 12.18 to $28.99 \mathrm{~m}^{3} /$ day depending on head. 
Monthly average solar irradiation and array energy output analysis in Figure 7. The average value of solar irradiation range from 5.7 and $7.1 \mathrm{kWh} /$ day. The average value of final PV system yield range from 5.1 and $5.9 \mathrm{kWh} /$ day.

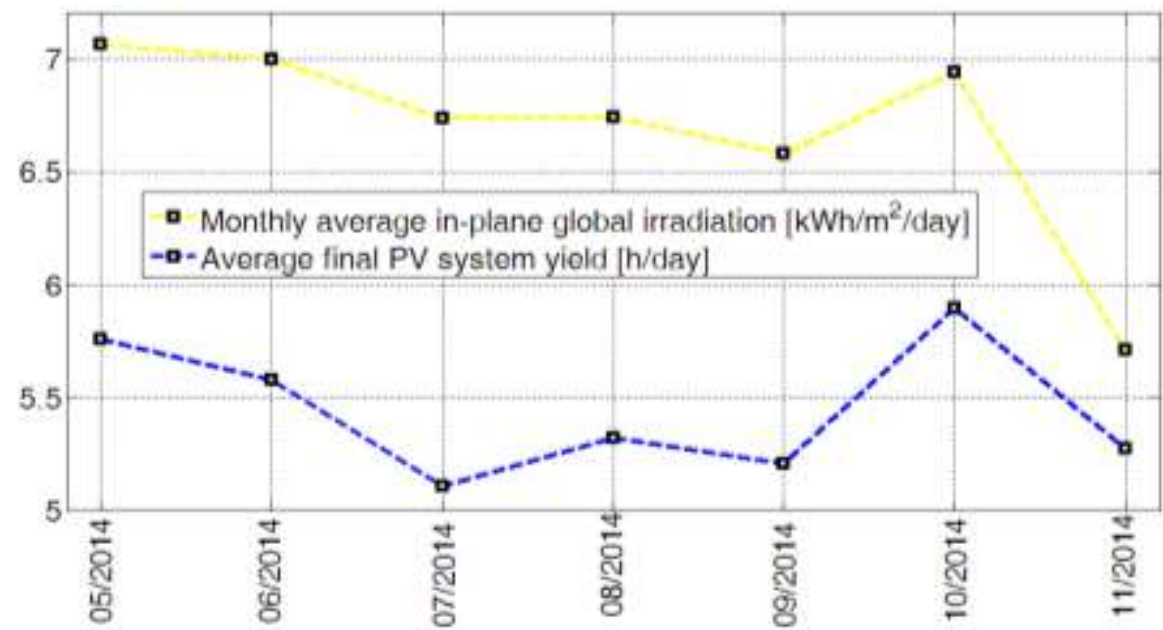

Figure 7. Total solar radiation and array energy output

Monthly performance ratios are summarized in next Figure; it shows the monthly PR based on the rated $\mathrm{P}_{\mathrm{AS}}$ values of the modules. A direct comparison between the performance ratio of the PV array shows that the PR for seven months is within the range of 76\%-93\%. Performance ratios were lower in summer and higher in winter. In this particular comparison it is obvious that the PV systems which provided the highest energy yield also had the highest PR values. In addition, for example in May, a high solar irradiation is occurred, but the system shows low PR, while in November a low solar irradiation is registered, but the system shows a high PR. A direct comparison between the months September and November, the solar irradiation of November was relatively smaller than the September, but the array energy output in November was higher than that of September. It is worth noting that the PR as such does not represent the amount of energy produced because a system with a low PR in a high solar resource location might produce more energy than a system with a high PR in a low solar resource location.

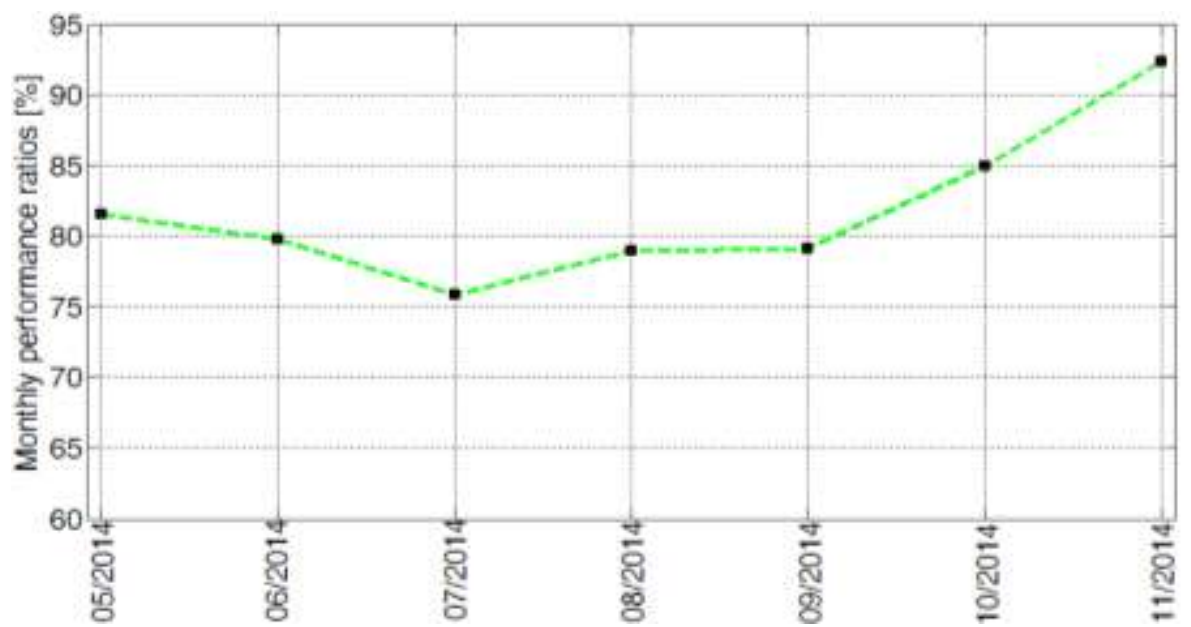

Figure 8. Monthly performance ratios 
In order to compare this performance with other previous studies in the literature, we have adjusted the performance in our system according to the results of the other system installed years ago in Japan [9], Belgium [2], Korea [3] and Germany [4]. As a comparison, annual ration the performance around the $72 \%, 84 \%, 78 \%$ and fairly low PR lower than $80 \%$ is obtained $(50 \%$ of systems in 2010 show PR> $83 \%$ ) were reported for PV systems installed years ago in Japan Belgium, Korea and Germany, respectively.

The PR for the PV systems installed in Japan were relatively small than the abovementioned PR, related primarily to row shading (because the PV arrays was shaded, the orientation of array mounted on the eaves had faced east-south, PV arrays on $2^{\text {nd }}$ and $3^{\text {rd }}$ floors were especially shaded by the upper part of the building in seasons at the high solar elevation) and bad inverter performance (Frequent inverter suspension in high grid-connected voltage) [10].

\section{Losses analysis}

Losses are calculated for seven months separately for each month. Figure 9 shows the histogram of different losses on mc-Si PV modules. For example, the value of shading losses in this PV system was $2.69 \%$ in $07 / 2014$ and $0.6 \%$ in $11 / 2014$. The maximum value of $\lambda_{\mathrm{HS}}$ was less than $3.01 \%$, of which are considered excellent, because our PV modules are installed for sunlit region (non shadow). In Japan $[6,7,10]$, the annual average of these losses was $7 \%$; because in Japan, grid-connected building integrated photovoltaic systems are becoming a popular feature in the built environment in many of the developed countries. This system forms an integral part of the urban edifices such as: envelopes, rooftops, pergolas, shading devices, etc.

To the contrary, array efficiency decrease losses by temperature. In Japan $[6,7,10]$, the annual average of these losses is found to be between $\sim 2 \%$ and $\sim 4 \%$; the monthly average array temperature of its system can be negative. The average of affect temperature losses on the $\mathrm{PV}$ modules in our region was $8.41 \%$. This means that the positive effect of the increase in monthly solar energy incident on the PV modules in our region is compensated by the negative effect of the increase in modules surface temperature. Seasonal trend of the loss due to the temperature was almost the same in all days for same month. Higher temperature caused more loss in summer and colder temperature resulted less loss or even gain in winter. In 07/2014, the monthly rate of loss factor such as array temperature increase loss $\left(l_{\mathrm{PT}}\right)$ was relatively large as $10.56 \%$, is believed very reasonable.

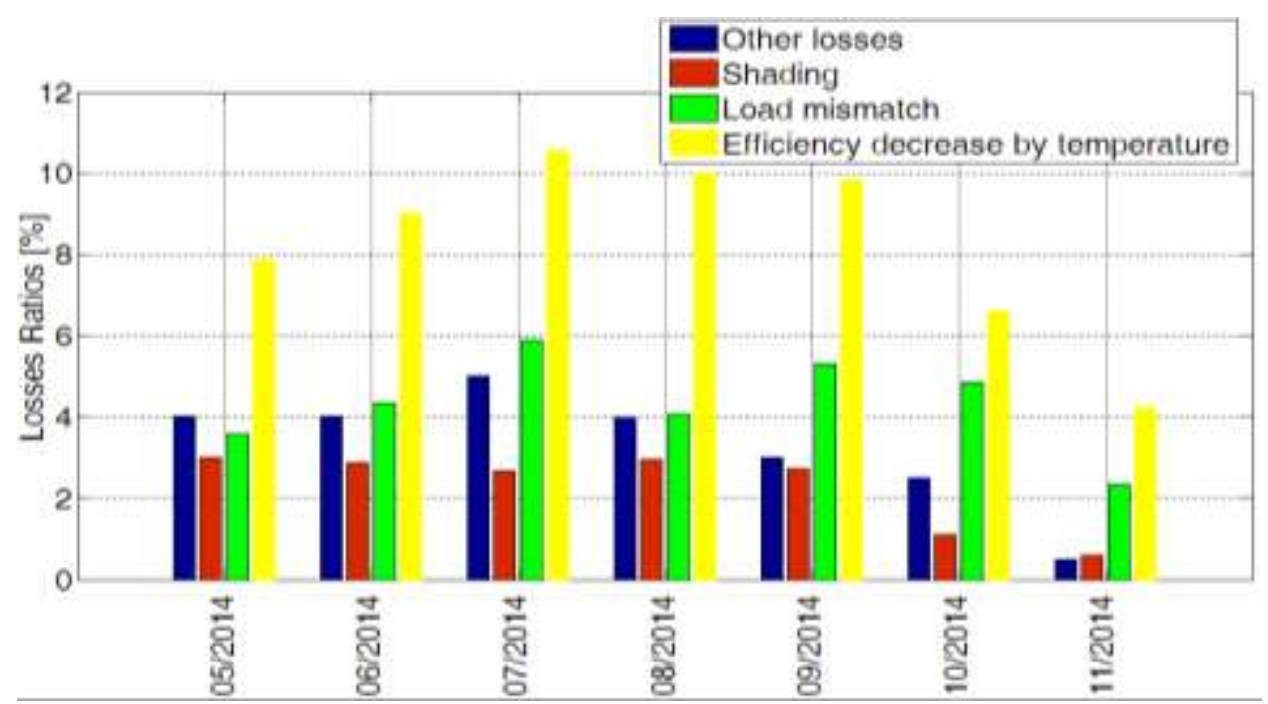

Figure 9. An evaluation result by the SV method 
The load mismatch losses $\left(l_{\mathrm{PM}}\right)$ are demonstrated in Figure 10 . The average of $4.4 \%$ is considered also excellent. It is thought that MPPT work very well. The results shows that the monthly load mismatching losses of the PV systems installed in Algeria has the same values as the monthly load mismatching losses of the PV systems installed in Japan.

The average of other array losses became $4 \%$ in summer. Although this is caused by soiling on module surface, incident-angle-dependent reflection losses, array circuit losses and mismatch, etc, in principle, the losses of soilure (dust due to sands wind) and the incident-angle-dependent losses are believed to be major parameter, but the incident-angle-dependent reflection losses cannot be easily reduced. This may be caused by most solar rays not perpendicular to module glass surface in some months as May, Jun, July and August.

Figure 10 gives the quick summary of the average of all the parameters which have been analyzed by the SV method for PV module.

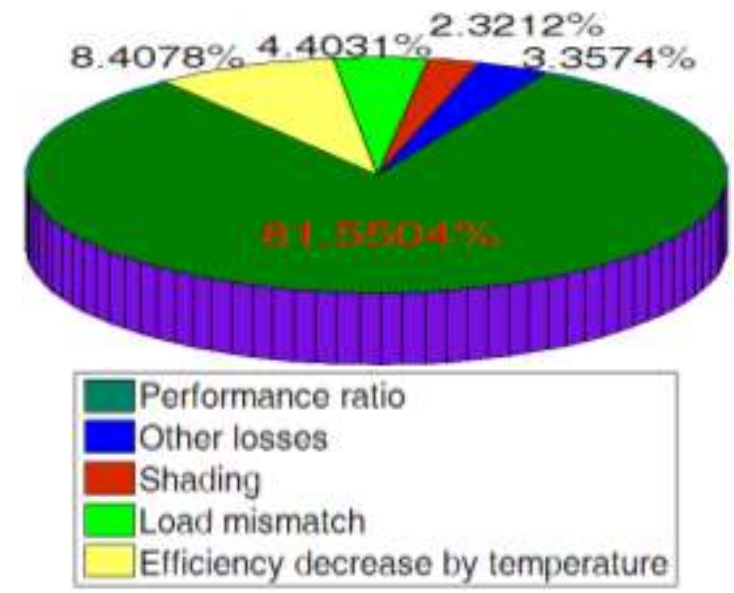

Figure 10. A total evaluation result of PV module by the SV method for 7 months

We can define a new rating plate of photovoltaic modules using energy yield at maximum power operation for a set of defined standard test day conditions. To encourage PV module manufacturers to develop PV modules that optimize energy production as follows in Table 3 not power at a single rating condition, typically STC.

Table 3. New rating plate

\begin{tabular}{|l|l|l|}
\hline Module Type & mc-Si Solar ET-M53675 & \\
\hline $\mathrm{P}_{\max }$ & $75 \times 2$ & $\mathrm{~W}$ \\
\hline $\mathrm{I}_{\mathrm{pm}}$ & 4.31 & $\mathrm{~A}$ \\
\hline $\mathrm{V}_{\mathrm{pm}}$ & $17.4 \times 2$ & $\mathrm{~V}$ \\
\hline $\mathrm{I}_{\mathrm{sc}}$ & 4.72 & $\mathrm{~A}$ \\
\hline $\mathrm{V}_{\mathrm{oc}}$ & $21.73 \times 2$ & $\mathrm{~V}$ \\
\hline $\mathrm{E}_{\mathrm{P}}$ (Adrar, Summer) & $\mathrm{P}_{\mathrm{AS}} \cdot \mathrm{H}_{\mathrm{P}} \cdot \mathrm{PR}=0.15 \cdot 7 \cdot 0.78=0.82$ & $\mathrm{kWh} /$ day \\
\hline $\mathrm{E}_{\mathrm{P}}$ (Adrar, Winter) & $0.15 \cdot 6 \cdot 0.91=0.82$ & $\mathrm{kWh} /$ day \\
\hline
\end{tabular}

Generally, if PR is under $65 \%$, various troubles concerning the system performance obstruction such as the shading, inverter MPPT mismatch, etc. will be suggested to be more investigated. The results the outdoor exposure tests will clarify the degradation mode of PV modules, and will leads to the fabrication of the anti-degradation PV modules with higher reliabilities. It will help to make energy rating of photovoltaic modules under real operating conditions and help of existing PV systems to find troubles/failures. i.e. to be introduced to the diagnosis of the system PV. But the performance ratio did not always to identify us 
components that are not working properly; it must make the survey for each component of PV systems.

Monthly system efficiency was determined and depicted in Figure 11 together with monthly array efficiency and subsystem efficiency. The average daily array PV efficiency was $10.3 \%$. The global efficiency of the system, as can be seen from Figure 11, is low, do not exceed $2.98 \%$. Average total system efficiency is dominated by array and subsystem efficiencies. Figure 11 show that increase head (from $1.6 \mathrm{~m}$ to $3.95 \mathrm{~m}$ ) increases subsystem efficiency (from $13.025 \%$ to $26.935 \%$ ) and system efficiency (from $1.27 \%$ to $2.974 \%$ ). This is caused principally by the deviation of the working points of the subsystem components (mainly the pump) from the nominal rated range. To show the effect of pumping head profile on system performance and to determine the optimum pumping head profile. Mismatch of pumping head and pump rated head results in significant efficiency losses, this may occur due to poor design. As can be seen in this Figure, it is difficult to conclude which pumping head profile is the optimum. Effect of pumping head on subsystem efficiency is more significant. As subsystem efficiency is the most significant parameter, Figure 11 shows that the corresponding head at maximum subsystem efficiency is $3.95 \mathrm{~m}$.

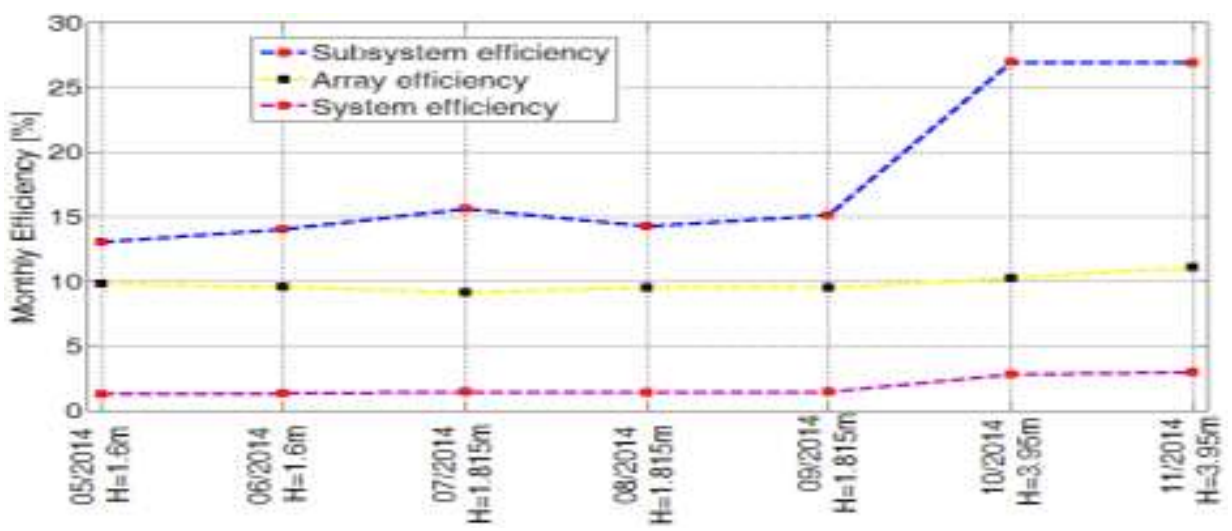

Figure 11. Monthly system efficiency as a function of heads

\section{Conclusions}

The evaluation of PV systems is very important for an efficient design. For that purpose, the SV method which is very simply and accurately evaluation method in Saharan climates was applied and empirically validated. The evaluation was done with an actual operating PV pumping system data in the Algeria's Sahara city of Adrar. Average performance ratio for the PV array during seven months was found $81.5 \%$. Higher temperature caused more loss in summer and colder temperature resulted less loss in winter. The solar irradiation in winter was relatively smaller than in summer, but the PV arrays provides same average energy output in two seasons. This means that the positive effect of the increase in the number of peak sunhours in summer is compensated by the negative effect of the decrease average PR for the PV array. This monitoring data can be used for making a feedback on technical information like, power losses by shading on the PV array, power losses by dust covered on the PV array and a hot bypass diode or a dead section in the PV module. We encourage various PV module manufacturers to enrich their rating plate not by power at a single rating condition, typically STC but by energy under various conditions.

According to other previous studies in the literature, annual PR for the PV systems installed in Germany shows a median PR of $84 \%$. We therefore conclude that for the case of German climate, the system PV provides good performances. The PR for the PV systems installed in Japan was relatively small than the PR for the PV systems installed in Saharan region of Algeria, Belgium and Germany. 
For provides useful information about the seasonal behaviour of any PV technology, by the evaluation of the long term performances of PV module in the severe natural environment, it is necessary deployed the PV system for at least for more than a year. We will continue the performance study of our PV system.

Subsystem efficiencies as a function of system pumping head were investigated. Monthly efficiency at optimum head was found as: $26.93 \%$ for the subsystem, $2.9 \%$ for the PV system. The installation of pump with a pumping head causes efficiency pumping to be some $17 \%$ inferior to optimally pumping head.

\section{Acknowledgment}

The authors would like acknowledge the financial support of Japan International Cooperation Agency (JICA) and Japan Science and Technology Agency (JST) for their training in National Institute of Advanced Industrial Science and Technology (AIST) their support for the SSB project.

\section{References}

[1]. A. J. Carr, "A detailed performance comparison of PV modules of different technologies and the implications for PV system design methods", Ph.D. Murdoch University, Western Australia, July 2005.

[2]. J. Leloux, L. Narvarte, D. Trebosc, "Review of the performance of residential PV systems in Belgium", Renewable and Sustainable Energy Reviews 16 (2012) 178- 184.

[3]. J.H. So, Y.S. Jung, G.J. Yu, J.Y. Choi, J.H. Choi, "Performance results and analysis of 3 kW grid-connected PV systems", Renewable Energy 32 (2007) 1858-1872.

[4]. N.H. Reich, B. Mueller, A. Armbruster, W.G.J.H. M. van Sark, K. Kiefer and C. Reise, "Performance ratio revisited: is PR>90\% realistic?", Progress in photovoltaic's: research and applications prog. photovolt: res. appl. 2012; 20:717-726.

[5]. M. Drif, P. J. Pérez, J. Aguilera, J.D. Aguilar, "A new estimation method of irradiance on a partially shaded PV generator in grid-connected photovoltaic systems", Renewable Energy 33 (2008) 2048-2056.

[6]. K. Kurokawa, D. Uchida, K. Otani, "Sophisticated Verification PV of simple monitored data for Japanese field test program", $2^{\text {nd }}$ World Conference and Exhibition on Photovoltaic Solar Energy Conversion, Vienna, Austria, July. 6-10, 1998.

[7]. T. Oozeki, T. Izawa, K. Otani, K. Kurokawa, "An evaluation method of PV systems", Solar Energy Materials \& Solar Cells 75 (2003) 687-695.

[8]. Y. Ueda, Y. Tsuno, M. Kuda, H. Konishi, K. Kurokawa, "Comparison between the I-V mesurement and the system performance in various kinds of PV technologies", $5^{\text {th }}$ WCPEC/25 $5^{\text {th }}$ EUPVSEC, Valencia, Sep 2010, pp. 6-10.

[9]. B. Marion, J. Adelstein, K. Boyle, H. Hayden, B. Hammond, T. Fletcher, B. Canada, D. Narang, D. Shugar, H. Wenger, A. Kimber, L. Mitchell, G. Rich, and T. Townsend, "Performance Parameters for Grid-Connected PV Systems", $31^{\text {st }}$ IEEE Photovoltaics Specialists Conference and Exhibition, Lake Buena Vista, Florida, February 2005.

[10]. T. Sugiuraa, T. Yamadaa, H. Nakamuraa, M. Umeyaa, K. Sakutab, K. Kurokawa, "Measurements, analyses and evaluation of evidential PV systems by Japanese monitoring program", Solar Energy Materials \& Solar Cells 75 (2003) 767-779.

[11]. D. Uchida, K. Otani, K. Kurokawa, "Evaluation of effective shading factor by fitting a clear-day pattern obtained from hourly maximum irradiance data", Solar Energy Materials \& Solar Cells 67 (2011) 519-528.

[12]. K. Kurokawa, H. Sugiyama, D. Uchida, K. Sakamoto, T. Ohshiro, "Realistic PV performance values obtained by a number of grid-connected systems in Japan", North Sun '99 $8^{\text {th }}$ Intern. Conf. on Solar Energy in High Latitudes, Edmonton, Canada, Aug. 1114, 1999. 
[13]. M. Benghanem, K.O. Daffallah, A.A. Joraid, S.N. Alamri, A. Jabe, "Performances of solar water pumping system using helical pump for a deep well: A case study for Madinah, Saudi Arabia", Energy Conversion and Management 65 (2013) 50-56.

[14]. I. Odeh, Y.G. Yohanis, B. Norton, "Influence of pumping head, insolation and PV array size on PV water pumping system performance", Solar Energy 80 (2006) 51-64.

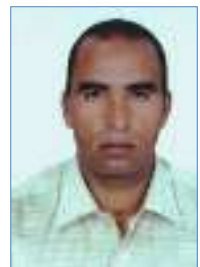

Mohammed Yaichi was born on 1980 in Adrar, Algeria. He received the Engineer degree in Electrical Engineering from University of Bechar, Algeria, in 2003, and the magister degree from Djillali Liabes University, Sidi-BelAbbes, Algeria in 2006. He is currently working toward the doctorate degree in the Power Electronics, and the Photovoltaic Pumping System. Since 2009, he is with the Photovoltaic Pumping Team, Research Unit in Renewable Energies in the Saharan Medium (URER/MS) Adrar, Algeria. His research interests include a study on performance improvement of a stand-alone photovoltaic pumping system, variable-speed AC motor drives, and different multilevel inverter circuit topologies thus its technique of control PWM.

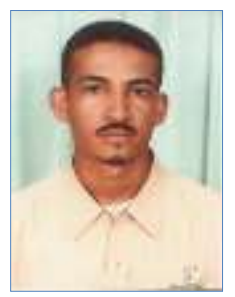

Abdelkrim Mammeri was born on 1979 in Bechar, Algeria. He received the Engineer degree in Hydraulic from University of Sciences and Technology, Oran, Algeria, in 2006, and now studying for master degree. Since 06/11/2006, he is with the Photovoltaic Pumping Team, Research Unit in Renewable Energies in the Saharan Medium (URER/MS) Adrar, Algeria. His research interests include a study on performance improvement of a standalone photovoltaic pumping system.

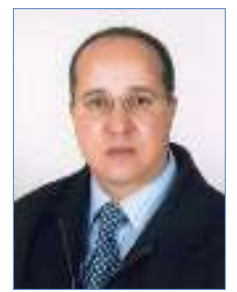

Mohammed-Karim Fellah was born in Oran, Algeria, in 1963. He received the Eng. degree in Electrical Engineering from University of Sciences and Technology, Oran, Algeria, in 1986, and the Ph.D. degree from National Polytechnic Institute of Lorraine (Nancy, France) in 1991. Since 1992, he is Professor at the University of Sidi Bel-Abbes (Algeria) and Member of the Intelligent Control and Electrical Power. His current research interest includes Power Electronics, HVDC links, and Drives. 